Ezmolda Barolli*, Kozeta Sevrani**

\title{
Reflections on e-Learning Readiness in Albanian Education
}

\section{Summary}

Nowadays e-Learning has been identified to be the future of learning worldwide since the very powerful platform of the Internet has accelerated the speed of communication. Adoption of e-learning has become the latest trend across universities all over the world. Albania is part of a global shift from material resources to knowledge and intellectual resources as the basis for economic growth. Educators across Albania are aware that students must have an education that enables the students to participate successfully in and contribute to the knowledge economy. E-Learning readiness is an initial part of eLearning development. In order to benefit from e-learning, higher education institutions in Albania should conduct considerable up-front analysis to assess their readiness. In this paper we are trying to examine the status of e-Learning readiness in Albania, analyzing and discussing several components and criteria based on literature.

\section{Introduction}

E-learning is becoming increasingly prominent in tertiary education. It is actually changing the way how teachers teach and students learn. E-learning introduced since 1990s has improved teaching and learning styles, and qualities. The explosive growth in Information Technology (IT) and new developments in learning science provides opportunities to create well-designed, learner-centered, meaningful distributed and

* MBA, Mathematics, Statistics and Applied Informatics Department, Faculty of Economy, Tirana University, Albania.

${ }^{* *}$ Prof. dr, Mathematics, Statistics and Applied Informatics Department, Faculty of Economy, Tirana University, Albania. 
facilitated e-learning environments (Khan, 2005). E-learning represents an innovative shift in the field of learning, providing rapid access to specific knowledge and information, and offers online instruction that can be delivered anytime and anywhere through a wide range of electronic learning solutions such as a web-based courseware and online discussion groups. It can be viewed as making learning materials such as presentation slides available on the web. Nowadays e-learning has become an accepted educational paradigm across universities worldwide (OECD, 2005).

There are many definitions given to e-learning. E-Learning refers to the use of Information and Communications Technology (ICT) to enhance and/or support learning in tertiary education. But this covers a wide range of systems, from students using e-mail and accessing course work online while following a course on campus, to programs offered entirely online. This implies that e-Learning refers to both wholly online provision and campus-based or other distance-based provision supplemented with ICT in some way. The supplementary model would encompass activities ranging from the most basic use of ICT (e.g. use of PCs for word processing of assignments) through to more advanced adoption (e.g. specialist disciplinary software, handheld devices, learning management systems, adaptive hypermedia, artificial intelligence devices, simulations, etc.), with a presiding interest in more advanced applications.

E-Learning has been identified to be the future of learning worldwide since the very powerful platform of the Internet has accelerated the speed of communication. E-Learning offers remarkable advantages to the economy (Strother, 2002) when gathering large groups of students. Based on meta-analysis research, academic achievement of online students equalized traditional instruction (Cavanaugh, 2007). E-Learning is not only the student preferred mode of learning but also the preference of teachers (Strother, 2002). In American institutes, e-Learning has become a "critical" component of the long-term planning strategies (Allen and Seaman, 2006).

According to John Chambers (Rosenberg, 2001), "the biggest growth in the Internet, and the area that will prove to be one of the biggest agents of change, will be in elearning." The demand for a well-educated workforce has driven many countries to rethink their education systems. An education system has to be suited to the demands of the technological age so that a competitive edge can be maintained. Such demand for a technology savvy workforce is reflected in Alvin Toffler's declaration (Rosenberg, 2001), that "the illiterate of the 21 st century will not be those, who cannot read and write but those who cannot learn, unlearn, and relearn." An ancient proverb says: "if we don't change our direction, we'll end up exactly where we are headed" (Rosenberg 2001). This indicates that learning institutions will have to constantly change and adapt in their environments if they are not to lag behind.

The promises of e-learning for institutions of tertiary education are manifold, but too often they fail to take effect. The reason is a not sufficient readiness to take up e-learning in the faculties and absorb the innovation effects coming along with it. E-learning is a good opportunity for faculties but they needs to be well prepared because it takes often high investment costs and well designed strategies. That is why it is important for an institution to know if it is e-ready. In this paper we suggest e-learning readiness as a key factor influencing the uptake of e-learning in universities. E-readiness is already well 
covered in literature and several models are suggested, some of them we are discussing in the next section.

\section{E-Learning readiness. Literature review}

Government, Industry, Education, and Society are identified as the key components in the first level of e-Learning readiness. In the second level, the readiness are estimated based on the connectivity, the capability - a country's ability to deliver and consume e-Learning, literacy rates, and trends in training and education - content and culture (Borotis, Poulymenkou). Rosenberg focused on the concept of sustainability and proposed the components of business readiness, changing nature of learning and e-Learning, value of instruction and information, role of change management, reinvention of training organizations to support e-Learning efforts, e-Learning industry, and personal commitment (Rosenberg, 2000). Chapnick posed the components of psychological, sociological, environmental, human resource, financial, technology, equipment, and content readiness (Chapnik, 2000). The overall e-learning readiness is defined by seven key components. Business Readiness refers to the link of organizational business priorities and characteristics, to e-Learning efforts. Organizations operate in a highly competitive environment where strategy, environment, and smoothness of internal problems affect primarily their viability and profitability. Technology Readiness focuses primarily on the technical infrastructure. Content Readiness studies issues concerning e-Learning content material such as interactivity, reusability, interoperability, etc. Training Process Readiness refers to the ability of organizations to organize, analyze, design, develop, implement and evaluate a concrete training program. Culture Readiness determines organizations' perceptions and cultural parameters concerning e-Learning adoption and use. Human Resources Readiness refers to the availability and set-up of the human - support system. In this component some parameters such as receptivity and the prerequisites of humans to learn successfully in the new environment are defined. Financial Readiness refers to the budget allocation and investment for establishing a robust e-Learning setup (Borotis, Poulymenkou).

According the Economist Intelligence Unit (EIU) e-Learning readiness means more than connectivity. The best-connected countries in the world, led by Singapore and South Korea, are not necessarily the top e-learners. Other building blocks - including a strong education system and a wealth of online content - are also necessary, as is a willingness to adapt to new ways of learning. Since 2000, the Economist Intelligence Unit has published an annual e-readiness ranking of the world's 60 largest economies (eb.eiu.com/err). The ranking provides a benchmark for governments seeking to make their economies amenable to Internet and high-tech investment, and companies aiming to direct their investments to the most receptive countries. In 2003, in response to important new trends in Internet usage, EIU published a complementary ranking: e-learning readiness in the same 60 countries. E-learning readiness indicates a country's ability to produce, use and expand Internet-based learning - both informal and formal, at work, at school, in government and throughout society. It has arranged the criteria in the ranking in four main areas: 
- Connectivity (the quality and extent of Internet infrastructure),

- Capability (a country's ability to deliver and consume e-learning, based on literacy rates, and trends in training and education),

- Content (the quality and pervasiveness of online learning materials),

- Culture (behaviors, beliefs and institutions that support e-Learning development within country).

In this paper we are trying to examine the status of e-Learning readiness in Albania, analyzing and discussing several components and criteria mentioned before.

\section{Building foundation for e-Learning in Albania}

Albania is part of a global shift from material resources to knowledge and intellectual resources as the basis for economic growth. The knowledge economy is driven by the requirement for rapid innovation in competitive global markets, and is enabled by the capacity of ICT to store, process and deliver information. Educators across Albania are aware that students must have an education that enables them to participate successfully in and contribute to that world. Despite its advantages, e-learning in Albania is still in its infancy stage; however Albanian governments are supporting major programs to increase the use of ICT in universities.

\subsection{Supportive policies for e-Learning}

Albania is tackling its digital divide problem from the roots up by encouraging more ICT use in schools across the country. With the support of the United Nations, the Albanian Ministry of Education and Science is putting together plans for a comprehensive new e-School program giving primary and secondary students in Albania much-needed internet and IT skills and knowledge. On the other hand for as much as education will be one of the main priorities of the Government, it takes an important part in the National Information and Communication Technologies Strategy. Any action in support of research and university education in the ICT sector must conform to any general reform undertaken by the Ministry of Education and be aligned with the planned modification of the law of education.

One of the goals of the strategy is "Promoting Basic Computer Literacy - ICT Education for all". Literacy is obviously a prerequisite for use of ICT - activities carried out within this goal have to assume basic literacy. The Ministry of Education has developed plans for equipping high schools with computers and Internet access, as well as for establishing the Albanian academic research network. The activities described underneath will integrate and, where necessary, revise the existing plans of the Ministry of Education. This goal aims at a broad education about ICT, use of computers and the information society throughout the whole population, with as broad a reach as possible, in order to achieve a wide computer literacy. Although the emphasis is on delivering ICT education, the government will provide the necessary legal and regulatory framework to stimulate ICT education, oriented at European Union legislation and in particular at the 
Bologna Declaration for Education. In order to achieve this goal, other economic policies can be applied that aim through different incentives to reduce computers prices and provide free internet access for University pedagogic staff.

Some of the strategic activities proposed are:

- ICT Education in schools. The activity comprises the provision of computers and connectivity of schools in urban and also in rural areas, training of the teachers and developing curricula for informatics education in schools.

- Adult Education and training in basic computer literacy. Curricula for adult education will be developed and offered by the state based on available infrastructure in schools. Courses should be offered in English and in Albanian. Television and other public media should play a role in providing basic computer literacy, especially in remote areas without easy access to Internet and computer networks.

- Certification (e.g. ECDL). The provision of training by private organizations requires the development of certificates by government or independent organizations.

- ICT for training in non-ICT related subjects. Based on the existing training infrastructure training courses will be developed and delivered in other subjects than ICT. Technology used could be multi-media or E-Learning. TV broadcast could be used as well.

- General awareness creation among the population. It will be necessary, in addition to the educational and training actions, to carry out awareness creation on a broad basis with the goal to inform everybody about the information society and to reach the whole population.

The other goal of this strategy is "Creating well qualified staff in ICT field". Education of professionals is particularly related to the problem of brain drain - highly educated ICT specialists are most inclined to leave the country, since they have the best chances to find a well remunerated employment abroad. Therefore, additional strategies will have to accompany the education of ICT specialists, which are the creation of attractive working conditions in Albania, a market for ICT products in the country, and in particular opening up the Albanian ICT market to the international market. This goal deals with higher level ICT education in a general sense, provided in universities, vocational training institutes, specialized courses, in-house training, training centers, research organizations, etc. ICT courses could be delivered by the public and also by the private sector. Collaboration in public-private partnership will be essential to define the necessary curricula. The promotion of the participation of ICT specialists from public organizations in ICT training and education will have a priority.

Some of the strategic activities proposed are:

- Certification of higher level ICT education. Two different types of certificates exist, one provided by industry, the second one provided by the state for degrees such as diplomas, for which the Ministry of Education is responsible.

- ICT education in Albanian universities. The Ministry of Education will introduce measures to increase the level and quality of the education of ICT professionals in Albanian universities, both under-and post-graduate. This could mean changes in the 
structure or curricula of universities, as well as encouraging joint operation with similar foreign institutions with the purpose to obtain mutually recognized diplomas.

- Research in ICT. Measures will be defined to stimulate high level research work in universities and research organizations. Participation in international research programs will be supported, as well as the use of research networks for national and international collaboration in science and research.

- Distance Learning in ICT. Development of content and tools for distance learning, collaborative working or E-Learning in universities will be supported, focusing on ICT education and training. In particular, distance learning courses provided by famous universities abroad should be made available. As a long-term goal, the creation of a virtual university will be envisaged.

- Vocational ICT Training for ICT technicians. Non-university degrees in ICT will be created for ICT professions such as technicians or programmers. Several different degrees will be envisaged, as well as life long learning offered.

\subsection{Computer networking facilities at the major research and education institutions}

There are 11 public universities in Albania, with the major ones, the University of Tirana and the Polytechnic University of Tirana counting about 20000 students, roughly half of the country's entire student population. The University of Tirana has several faculties and institutes in Tirana, located at a number of different sites, some of which are campus-like sites aggregating several institutes; occasionally several institutes are hosted in the same building. The whole university counts more than 15000 students and more than 1000 teachers. Two departments at the University of Tirana have ICT facilities and related expertise: the Department of Mathematics, Statistics and Applied Informatics of the Faculty of Economy and the Computer Sciences Department of the Faculty of Natural Sciences. Besides the University of Tirana, the other institute with a major Computer Sciences department in Albania is the Faculty of Electrical Engineering of the Polytechnic University of Tirana. Because of their expertise, the Faculty of Natural Sciences of the University of Tirana, and the Faculty of Electrical Engineering of the Polytechnic University of Tirana represent the best opportunity in Albania concerning ICT and networking and should be the main focus for running the academic network. There is no academic network in Albania and there is also no network interconnecting the buildings of the University of Tirana. All institutions have separate, generally low-bandwidth, connections to the Internet via several ISPs. Actually all the Higher Education Institutions have their local network and internet provided in independently from each-other. Most of the universities have a poor and old ICT infrastructure. In practice universities do very little or no research at all, because of lack of facilities, but also because institutes can generate additional revenues by providing services to third parties. Moreover, it is not unusual for academic staff members to take unrelated commitments in business/ management activities outside of the university.

The Faculty of Economy of the University of Tirana has about 5000 students, provides courses in applied informatics for students of Finance, Business Administrations 
and Economics, and also confers a diploma in Economics Informatics. The Faculty participates in programs for the exchange of staff and students and has some international collaboration with Nebraska and German Universities, as well as with the UK, Greece and Italy. Only a small number of the faculty PCs, mainly used for the administration, are connected by a LAN. The Faculty has two computer labs, but these are fully occupied all day long. They are too small for their needs. One has 25 machines plus server, the other 20 machines not connected, but the room contains a DELL Power connect 2016/2024. The Faculty is connected to the Internet via a wireless link to an ISP at download speed of 512k and upload speed of $128 \mathrm{k}$. The same access point is shared by 6 departments in the building. A new library in a second building connected to the Faculty has three PCs, one of which is connected via the same 512k link.

The Faculty of Natural Sciences of the University of Tirana has about 3000 students. The Faculty provides three-year and five-year degrees in such disciplines as Biology, Physics, Mathematics and Chemistry. The faculty provides also Computer Science courses. All three buildings of the Faculty of Natural Sciences are connected via a LAN with about 100 PCs and connected to the Internet via a leased line from a commercial ISP. In the recent years, this faculty has made possible the application of online courses for graduated students. Via e-Learning projects the students can take various courses, according their needs, for same classes like mathematics, physics, chemistry, biology and especially computer sciences. The full package of e-Learning systems is made possible by academic staff of the faculty itself, which provide for content and technical support.

The Faculty of Electrical Engineering of the Polytechnic University of Tirana is a major centre of expertise in informatics and computer sciences. However, labs and computer networking facilities are very poor. There had been projects about building a LAN infrastructure, but this was not available yet. The Robotics Lab and the Telecommunication lab have some PCs without network connections. The Multimedia Library has a few notebooks and one desktop for the administration, connected via $1 \mathrm{Mbp} / \mathrm{s}$ wireless link.

Interconnecting universities in Albania is one of the highest priorities of the recent development. The Italian office of development in cooperation with Ministry of Education and Science and other specialists of research will develop a project to build the telematic network among universities. This network will help to share the information among them in all fields of education and research. The project will provide also the infrastructure and the services for an information system supporting the integration of curricula, administrative information etc. to speed up the implementation of the Bologna process in Albania.

Albania has already obtained access to the current pan-European network for research and education, GÉANT, thanks to the SEEREN2 predecessor, the SEEREN FP5 project, which ended in December 2004. In the SEEREN2 project, two new institutions are involved: the Faculty of Electrical Engineering and the Faculty of Economy, while a third one, the Faculty of Natural Sciences, is considered as candidate. In order to improve Albania's current situation, where universities depend on separate connections to the Internet via commercial Internet Service Providers, contacts have been re-established at a national level between the Academy of Sciences and the Ministry of Education and 
Science. SEEREN2 aims at creating the next generation of the southeast European segment of GEANT, that intends to make leading-edge technologies and services available to the entire Research and Education communities and all scientific sectors without discrimination between users and sites in southeast Europe in an attempt to further ease the 'digital divide' that still separates most of the SE European countries from the rest of the continent. The ultimate goal is to consolidate the network and services into the panEuropean e-Infrastructure and the end-users into the European Research Area. This will promote the cooperation of scientific and educational communities of EU member states with the southeast European countries and will provide a platform for dissemination and development of next generation Internet technologies in those states that are on course to join the EU. During the year 2007, the Council of Ministers approved the status of Albania as an associated member of the FP7 Program. Besides the development of new technologies and their usages, FT7 provide the continuum of the yearlong project GEANT which connect the national academic networks with pan-European super network. The actual national program of research and development in ICT during 2007-2009, based on achieved results, the direction of actual national development, and the government goals, seeks to encourage further new development on ICT and in their usage.

\section{E-Learning readiness components with respect to Albania}

Relying on key components of e-Learning readiness mentioned in the second section we are trying to highlight some of these indicators with respect to Albania in comparison with the SEE countries or in a more wide range worldwide.

\subsection{Connectivity}

Across the board, successful e-learners have the right infrastructure. They lead in broadband connectivity, mobile-phone usage, and PC penetration. Without Internet

Figure 1. ICT Access Indicators

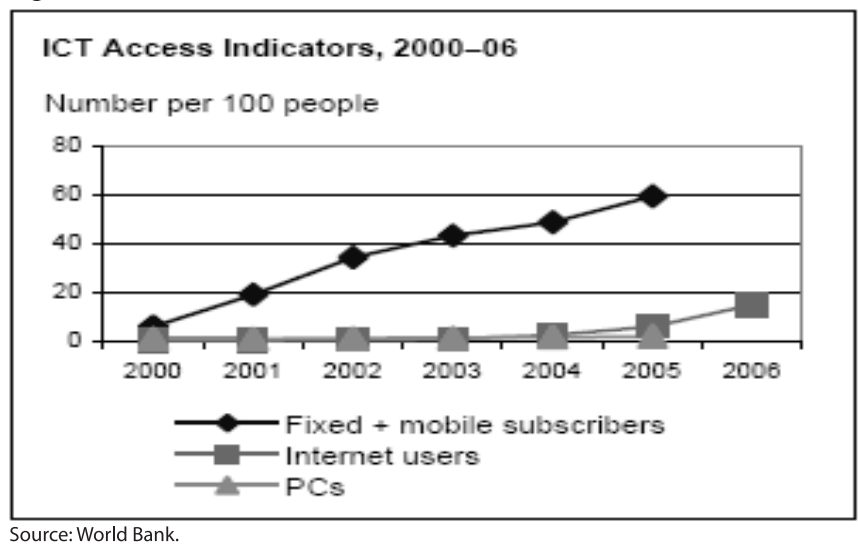


Table1. The Networked Readiness Index

\begin{tabular}{|c|l|c|}
\hline \multicolumn{2}{|c|}{ Global Competitiveness Report 2007-2008 $(N=131)$} \\
\hline 2007-2008 rank & \multicolumn{1}{|c|}{ Country/ Economy } & Score \\
\hline 1 & Denmark & 5.78 \\
\hline 2 & Sweden & 5.72 \\
\hline 3 & Switzerland & 5.53 \\
\hline$\ldots \ldots \ldots \ldots$ & & 4.47 \\
\hline 30 & Slovenia & 4.06 \\
\hline 49 & Croatia & 3.86 \\
\hline 61 & Romania & 3.71 \\
\hline 68 & Bulgaria & 3.49 \\
\hline 83 & Macedonia, FYR & 3.22 \\
\hline 95 & Bosnia and Herzegovina & 3.06 \\
\hline 108 & Albania & \\
\hline
\end{tabular}

Source: WEF (2007).

connectivity, there can be no online learning, and governments in both developed and developing countries are wise to continue prioritizing infrastructure rollout and upgrade. Albania has made progress during this decade, but still the figures are lower comparing with other countries, especially with the region.

Connectivity is an indicator of e-Learning readiness which is crucial to research for effective planning. A valuable tool for comparing countries is the Networked Readiness Index rankings of the World Economic Forum. Of the 131 countries rated in 2007, Denmark, Sweden and Switzerland were the most successful countries, ranked at 1, 2 and 3 respectively, but Albania fell below, in the 108 place (WEF 2007, table 1). The table 1 shows also the ranking of other SEE countries.

\subsection{Capability}

Connectivity is a crucial foundation, but additional building blocks are needed to spur e-learning: a strong education system, traditions in job training, support for lifelong learning and a high rate of literacy. In this area, which EIU term "capability", the leaders are Sweden, the US and Canada, followed by three countries in Asia-Pacific: South Korea, Australia and Singapore. Many countries, including many developing countries, value education highly. To create a competitive economy - one that is growing and generating future-oriented jobs - requires policy measures across many sectors, including education, particular tertiary education. Research done by the World Bank since the early 1990s shows that the development of higher education is correlated with economic development (World Bank 1994). A valuable tool for comparing countries is Higher education and training ranking. Of the 131 countries rated in 2007, Slovenia and Croatia were the most successful SEE countries, ranked at 39 and 57 respectively, but Albania fell below, in the 109 place (WEF 2007, table 2). 
Table 2. Higher education and training ranking. Performance of countries in SEE and CEE

\begin{tabular}{|l|c|c|c|}
\hline \multicolumn{1}{|c|}{ Global Competitiveness Report 2007-2008 (N=131) } \\
\hline Slovenia & Overall ranking & $\begin{array}{c}\text { Higher education } \\
\text { and training ranking }\end{array}$ & Innovation ranking \\
\hline Croatia & 39 & 24 & 30 \\
\hline Romania & 57 & 46 & 50 \\
\hline Bulgaria & 74 & 54 & 76 \\
\hline Macedonia, FYR & 79 & 66 & 88 \\
\hline Montenegro & 94 & 75 & 92 \\
\hline Serbia & 82 & 79 & 104 \\
\hline Bosnia and Herzegovina & 91 & 82 & 78 \\
\hline Albania & 106 & 98 & 121 \\
\hline
\end{tabular}

Source: WEF (2007).

\subsection{Content}

There is another basic building block for e-learning: online content. People must be able to access library materials, newspapers, corporate information, government databases, and much more, online and in their native language. This is a big issue since education through native language is important for the mass people. North America dominates in the rankings in online content, including e-learning content, followed by northern Europe. Countries where English is widely spoken are at an advantage, given the predominance of English-language content on the Internet. For this reason one of the priorities of the National Strategy of Education in Albania is the learning of English language in all levels of education.

According to IFLA/FAIFE World Report 2007 there are an estimated 40 public libraries in Albania (public library service points, including branch libraries), as well as 1700 school libraries, 15 university and higher school libraries, and 5 private university libraries. The number of government funded research libraries is given as 25 . Levels of Internet access in the country's libraries are correspondingly low. In the libraries where Internet access is provided, it is free of charge. It has been indicated that, during the last two years, the state has made extra funding available to improve Internet access. A large amount of local content on the Internet is available in Albanian, and often in English as well. Table 3 shows the percentage of internet access in all these libraries.

Now in case of introducing e-Learning we have to take an initiative to review all those existing material and then follow some way to ensure the reusability of the content. 
Table 3. Libraries and Internet access

\begin{tabular}{|l|c|}
\hline \multicolumn{1}{|c|}{ Population online* } & \multicolumn{1}{|c|}{$\begin{array}{c}\mathbf{4 7 1 2 0 0} \text { Internet users } \\
\text { (15.3\% penetration) }\end{array}$} \\
\hline Percentage of public libraries offering Internet access to users & Less than 20\% \\
\hline Percentage of school libraries offering Internet access to users & Less than 20\% \\
\hline Percentage of university libraries offering Internet access to users & 21-40\% \\
\hline $\begin{array}{l}\text { Percentage of government-funded research libraries offering } \\
\text { Internet access to users }\end{array}$ & $21-40 \%$ \\
\hline
\end{tabular}

Source: FAIFE World Report 2007.

* Online population numbers are from Internet World Stats (www.internetworldstats.com).

\subsection{Culture}

With connectivity, capability and content, e-learning is possible. But to truly flourish, other ingredients are required: beliefs, behaviors and institutions. In countries where the teaching profession is respected and rewarded, where learning is important to the general populace, and where there is a general acceptance of progressive ideas, there is immediate promise for e-learning ventures. Here Western Europe is ahead. Also in Albania the young people are interested in training for increasing their skill. Internet advancements are heartily welcomed by government and society alike, and there is a clear desire to leverage technology to reach ambitious and long-standing educational goals. Albanian government is developing plans and policies to welcome e-learning into public institutions, and support the validity of online degrees and certificates.

\section{Conclusions}

Albania is trying to transform itself into an information society. She has identified lifelong learning and reform of the education system, particularly higher education, as critical to its strategic goal of becoming a knowledge-based society. Adoption of elearning into educational institutions has been the latest trend worldwide and it has been proven very much effective in the process of teaching and learning. In order to benefit from e-learning, higher education institutions in Albania should conduct considerable upfront analysis to assess their readiness.

There are a number of instruments that can be used for assessing readiness for elearning. E-learning readiness indicates a country's ability to produce, use and expand Internet-based learning - both informal and formal, at work, at school, in government and throughout society. Economist Intelligence Unit has arranged the criteria for ranking the countries in four main areas: Connectivity (the quality and extent of Internet infrastructure), Capability (a country's ability to deliver and consume e-learning, based on literacy rates, and trends in training and education), Content (the quality and pervasiveness of online learning materials) and Culture (behaviors, beliefs and institutions that support e-Learning development within country). 
Comparing to the other countries, especially those of SEE, Albania has lower indicators according to the criteria of EIU about e-Learning readiness mentioned above. Nevertheless Albania is tackling its digital divide problem from the roots up by encouraging more ICT use in schools across the country. With the support of the United Nations, the Albanian Ministry of Education and Science is putting together plans for a comprehensive new e-School program giving primary and secondary students in Albania much-needed internet and IT skills and knowledge.

The general level of integration of ICT in teaching has increased greatly over the past years among the Albanian universities, too. However, most universities are still at the stage where the use of ICT consists of treating the computer as a sophisticated typewriter and as a means of facilitating communication via traditional pedagogy and didactics in the actual teaching situation, e.g. through the use of presentation programs, data-bases or simulation modules. Only a minority of universities have yet reached the stage of using ICT as a tool to redesign educational programs, content and curricula on the basis of novel didactic frameworks.

Interconnecting universities in Albania is one of the highest priorities of the recent development. It is very important the building of university networks that are interconnected through a national network, so that teachers, researchers and students will be provided with an advanced infrastructure for collaboration with their peers in Albania and abroad. During the year 2007, the Council of Ministers approved the status of Albania as an associated member of the FP7 Program. Besides the development of new technologies and their usages, FT7 provide the continuum of the yearlong project GEANT which connect the national academic networks with pan-European super network.

For the future, the main focus in the universities setting over the next years will be to upgrade their technological infrastructure. Almost all universities expect to have an intranet within the next 1-2 years, including plans by the vast majority of universities to offer digital services such as on-line registration for courses and examinations. The existence of an ICT strategy is a significantly important driver in the ICT developmental process. In this sense, the absence of conspicuous support and priority allocated by the university management to ICT integration and e-learning is a critical obstacle in many Albanian universities. In the years to come, incentives for the individual faculties, institutes and teachers to push the development of ICT further must be developed. The motivation to do so might be based on an awareness of the benefits obtainable from the integration of ICT, and on the availability of extra time for teachers to develop course material. In the future, ICT will not be limited to individual projects and fragments of an organization but will be incorporated into all its activities, and therefore the ICT unit will be of significant strategic importance. Nevertheless, there still seems to be a long way to go before these courses and support mechanisms become an integrated and essential aspect of normal university life. 


\section{References}

Chapnick S. (2000). Needs Assessment for E-Learning: ASTD (Infoline 0012) Cisco Systems Inc. (2001). Reusable Learning Object Strategy, Version 4.0. White paper, Cisco Systems Inc., Retrieved April 2004, from http://business.cisco.com/servletwl3/FileDownloader/iqprd/86575/86575_kbns.pdf

Chapnic S. (2005). Are you ready for e-learning? Learning Circuits: ASTD's Online Magazine All about e-learning.

Cavanaugh C. (2007), What Works in K-12 Online Learning, "Online Learning", vol. 2007: University of North Florida.

Country Report - Albania. IFLA/FAIFE World Report 2007.

Allen E., Seaman J. (2006), Making the Grade Online Education in the United States, The Sloan Consortium (Sloan-C).

ICT Strategy (2003). National Information and Communication Technologies Strategy. http://www.pad.gov.al/Content/e-Gov/StrategjiaTIK/ICTD_Strategy.pdf

ICT Strategy (2007). Project-proposal for the Inter-Sectorial Strategy on Information and Communication Tehcnologies and Telecommunications. Ministry of Public Works and Transport.

Strother J. (2002), An Assessment of the Effectiveness of e-learning in Corporate Training Programs [electronic version], "International Review of Research in Open and Distance Learning", vol. 3, pp. $1-9$.

Khan B.H. (2005). E-learning QUICK Checklist. Hershey, PA: Information Science Publishing. Retrieved December 30, 2007, from http://BooksToRead.com/checklist.

OECD (2005). E-learning in tertiary education: Where do we stand? Education \& Skills, 4, 1-293.

OECD (Organisation for Economic Co-operation and Development). 2007. Education at a Glance 2007. Paris: OECD.

Rosenberg M.J. (2001) E-learning: Strategies for Building Online Learning in the Digital Age. New York: McGraw-Hill.

Rosenberg M.J. (2000a). E-Learning: Strategies for Delivering Knowledge in the Digital Age: New York: McGraw-Hill.

Rosenberg M.J. (2000b). The E-Learning Readiness Survey. Retrieved February 2004, from www.books.mcgrawhill.com/training/elearning/eLearning_Survey.pdf

Spiros Ap. Borotis, Angeliki Poulymenkou, E-Learning Readiness Components: Key Issues to Consider Before Adopting e-Learning Interventions.

The Economist Intelligence Unit and IBM, The 2003 e-learning readiness rankings, 2003.

The Global Information Technology Report 2007-2008 (C) 2008 World Economic Forum

WEF (World Economic Forum). 2007. The Global Competitiveness Report 2007-2008. Geneva: WEF.

World Bank, ITU, WEF, Global Information and Communication Technologies Department and the Development Economics Data Group.

\section{Refleksje o wdrażaniu koncepcji e-learningu w systemie edukacyjnym Albanii}

\section{Streszczenie}

Od momentu rozwoju komunikacji internetowej koncepcja e-learnigu jest traktowana jako przyszłościowy system edukacyjny. Również uczelnie na całym świecie wprowadzaja platformy nauki na odległość poprzez wykorzystanie Internetu. Podobnie w Alba- 
nii. Ułatwiać to będzie rozwój gospodarki opartej na wiedzy i efektywne wykorzystanie zasobów intelektualnych kraju jako podstawy dla jego szybszego wzrostu ekonomicznego. Można stwierdzić, iż e-learning jest poczatkowa faza szerzej rozumianego e-rozwoju spoteczeństw. W artykule przeprowadzono wstępna ocenę stanu e-learningu w Albanii, głównie na podstawie ogólnych danych oraz badania literatury przedmiotu. 